\title{
The Perceptions of Global warming and Environmental Benefits of Biodiesel for Sustainable Energy Among High school Students in Jakarta
}

\author{
Desnita \\ Dept of Physic State Univerciti of Jakarta \\ Jalanpemuda No 10, Jakarta Timur. Indonesia \\ Desnita@yahoo.com
}

\begin{abstract}
The increased demand for energy, climate change, and energy security concerns has driven the research interest for the development of alternative fuel from plant origin. Biodiesel derived from plant oils, which include edible and non-edible oil have gained interest for the last two decades as alternative for diesel around the world. The purpose of this study was to determine the perceptions of high school students in Jakarta on the regarding renewable biodiesel. The study conducted a survey among twelve-grade. High school students studying in private schools in easten Jakarta in order to explore their perceptions of biodiesel production from non eedible oil and edible oil for heat and power. A total of 20 item questionnaires were administered to a total of 185 students in twelve grades. In addition, three open-ended questions were asked of the students in order to determine their level of knowledge regarding biodiesel, and power stations. The study data were analyzed using the SPSS statistical package program. The study results revealed that, the students were of the perception that biodiesel use would reduce global warming, and that renewable energy sources are environmentfriendly, non toxic and renewable.In addition, the students generally knew about biodiesel sources and their importance, although they lacked knowledge about certain aspects of biodiesel. The study recommends energy and educational policy makers to increase awareness of non edible and edible oil baseed bioenergy production among young students. In this respect, schools, parents, and media can also play an important role to engage young students in bioenergy related discussions.
\end{abstract}

\section{Indexing terms/Keywords}

Keyword : perception; global warming; highschool student

\section{Academic Discipline And Sub-Disciplines}

;Enviromental Education Studies;

\section{SUBJECT CLASSIFICATION}

E.g., sustainable energy

\section{TYPE (METHOD/APPROACH)}

Provide examples of relevant research types, methods, and approaches for this field: Survey/lnterview

\section{Council for Innovative Research}

\section{Peer Review Research Publishing System}

Journal: International Journal of Research in Education Methodology

Vol. 6, No. 3

www.ijrem.com, ijremeditor@gmail.com 


\section{ISSN 2278-7690}

\section{Introduction}

A large majority of the energy that is currently consumed around the world is provided by fossil fuels. The use of fossil fuels, in turn, causes the levels of $\mathrm{CO}_{2}$ in the atmosphere to increase. As

$\mathrm{CO}_{2}$ is a greenhouse gas, the increase in its atmospheric levels inevitably contributes to the natural greenhouse effect, leading to an increase in average temperatures worldwide. Global warming represents the most significant environmental problem of our age, and the resulting climate change has the potential to trigger many political, economic, and social crises around the world and to cause irreversible harm to both nature and the world in general. An UN commissioned group of scientists known as International Panel on Climate Change (PICC) confirmed that carbon dioxide is the main cause of global warning. According

to the reports of the PICC, the expected consequences of global warning include the alteration of hydrological cycles, the melting of glaciers around the world, the reduction of the total area of glaciers. Considerable aggregation of the gasses in the atmosphere surely results inintense climate change,acid rain and smog the rising of average sea levels, and the shifting of climatic belts [1].

The amount of "carbon dioxide equivalent" release in the world from 1990 is 6 billion metric ton,whichrepresentsan increase more than $20 \%$ [2]. For the first time in man's history,green house gas carbon dioxide in the atmosphere hits the record of 400 parts per million [3]. Fighting the increase of carbon emission is one of the principal reasons of the recent trend toward renewablenergy solution in Indonesia.

To reduce the numerous problems stemming from fossil fuel use is necessary the use of renewable energy [4].Sources of renewable energy include solar energy, wind energy, hydraulic energy, biomass energy, geothermal energy, and wave energy [5,] Renewable energy sources represent unlimited, clean, practical, economical [6] and environmentally friendly [7]energy sources. Moreover renewable energy such biodiesel does not contain any compounds like sulfur or aromatic compounds and burning of biodiesel results in lower emission of hydrocarbons, carbon monoxides and particulate matters [8]. Biodieselisnon-explosive, biodegradable,non-flammable, renewable,andnon-toxicaswell as environmentfriendly $[9,10,11]$. Biodiesel is the renewable energy mainly derived from vegetable oils or animal and holds great promise to replace petroleum-derived diesel in compression ignition $(\mathrm{Cl})$ engine [12].

One of the sources of renewable energy is biomass, which is known for its high potential to meet the energy requirement of a contemporary society, whether developing or industrialized [13]. Biomass means non-fossilized and biodegradable organic material originating from plants,animals and microorganisms. This shall also include products,by-products, residues and waste from agriculture,forestry and related industries as well as the non-fossilized and biodegradable organic fractions of industrial and municipal wastes. Biomass also includes gases and liquids recov- ered from the decomposition of nonfossilized and biodegradable organic material [14]. Nowadays, households and industries consume considerable volumes of fuel wood, farming products and residues, empty fruit bunches, animal wastes, and leaves [12]

\section{Biodiesel Feedstock}

The major feedstocks available for biodiesel are rapeseed, palm, canola and soybean oils, though the process to grow non-food grade oil is under process in the developing nations in tropic and sub-tropics. In the production of biodiesel more than $95 \%$ of feed stocks come from edible oils since they are mainly produced in many regions of the world and the properties of biodiesel produced from these oils are much suitable to be used as diesel fuel substitute.

Table1 General source of Biodiesel Feedstock

\begin{tabular}{|l|l|l|}
\hline No & Source of Biodiesel & Properties \\
\hline 1 & Palm Oil & $\begin{array}{l}\text { Palm (E. Guineensis) oil is derived from the seed of the palm, } \\
\text { and its trees are single-stemmed,and grow up to } 20 \text { m tall The } \\
\text { high oil yield of oil palm trees has made it efficient biodiesel } \\
\text { source }\end{array}$ \\
\hline 2 & Jatropha oil & $\begin{array}{l}\text { Jatropha planthasthebotanicalname J. curcas The seeds contain } \\
30-35 \% \text { oil by weight, which can easily be converted into bio- } \\
\text { diesel consists of both saturated (14.2\% palmitic acid and } 7.0 \% \\
\text { stearic acid) and unsaturated fatty acids (44.7\% oleic acid and } \\
32.8 \% \text { linoleic acid). }\end{array}$ \\
\hline 3 & Linseed oil & $\begin{array}{l}\text { Linseed hasthebotanicalname . usitatissimum, alsoknownas flax } \\
\text { seedoil,andisacleartoyellowishoilobtainedfromthedried } \\
\text { seedsoftheflaxplant.Thelinseedcontains35-45wt\%ofoil. } \\
\text { oilisobtainedbycoldpressing,alkalirefined,sunbleached, } \\
\text { thickenedandsometimesbysolventextractionmethod }\end{array}$ \\
& $\begin{array}{l}\text { The } \\
\text { sun }\end{array}$ \\
\hline
\end{tabular}




\begin{tabular}{|l|l|l|}
\hline 4 & Algae & $\begin{array}{l}\text { Algae (micro and macro) oils are one of the best sources for } \\
\text { synthesis of biodiesel because of their high oil content, rapid } \\
\text { biomass production (double their biomass production within 24 h) } \\
\text { and it is much faster and easier to grow }\end{array}$ \\
\hline 5 & Waste cooking oils & $\begin{array}{l}\text { Waste oil, includes residues from deep frying processes, such } \\
\text { assoap stocks, yellow and brown greases, obtained from } \\
\text { restaurants, hotels and industries. The free fatty acid content of } \\
\text { waste cookingoils ranges between } 10 \text { and } 25 \%,\end{array}$ \\
\hline
\end{tabular}

Biodiesel a processed fuel derived from the vegetable oils and animal fats through the esterification and transesterification reactions of free fatty acids (FFAs) and triglycerides, respectively, that occur naturally in renewable biological sources [15]. In other words we can define biodiesel is mixture of alkyl esters of long chain fatty acids, which are synthesized through esterification and transester- ification of free fatty acids (FFAs) and triglycerides (TG) [16].

\section{Processofbiodieselproduction}

Biodiesel productionfollowsTransesterification principle. Transesterification (alsocalledasalcoholysis)isthereactionof fat oroilwithanalcoholtoforestersandglycerol.Twostep catalyzed productionwasalsoreported [17]. Usuallyacatalystis used tomediatethereactionandbringoutquickerreactionrate. Aftertransesterification oftriglycerides,theproductsareamix- ture ofesters,glycerol,alcohol,catalystandtri-,di-andmono- $\quad$ glycerides.Basedontheprocessrequirements,therearevarious methods thatcanbeadoptedforproducingbiodieselfromvarious oil sources.Someofthemaredescribedinadetailedfashionand followsasgivenbelow.

\section{Tabel 2 Processofbiodieselproduction}

\begin{tabular}{|c|c|c|}
\hline No & Process & Properties \\
\hline 1 & Acid catalyzed process & $\begin{array}{l}\text { Acidcatalysisisthemostsuitablemethodincaseoforganic } \\
\text { substrates. Thetransesterification processiscatalyzedbyacidsand } \\
\text { catalystsgiveveryhighyieldsofalkylesters, butthereactions } \\
\text { areveryslow. Thehomogeneousacidcatalystsare } \mathrm{H}_{2} \mathrm{SO}_{4}, \mathrm{HCl}, \mathrm{BF}_{3}, \mathrm{H}_{3} \mathrm{PO}_{4} \text { and } \\
\text { someorganicsulfonicacids }\end{array}$ \\
\hline 2 & Alkali catalyzed process & Most widelyusedhomogeneousbasecatalystsare $\mathrm{NaOH}, \mathrm{CH}_{3} \mathrm{ONa}$ andKOH \\
\hline 3 & $\begin{array}{l}\text { Super critical methanol } \\
\text { process }\end{array}$ & $\begin{array}{l}\text { A fluid } \quad \text { isconsideredsupercriticalwhenitstemperatureand } \\
\text { pressuregoaboveitscriticalpointsincethereactioniscatalystfree,purification } \\
\text { ofbiodiesel is easy,environmentfriendlyandcompletesin2-4 min }\end{array}$ \\
\hline 4 & Biocatalyzedtransesterification & 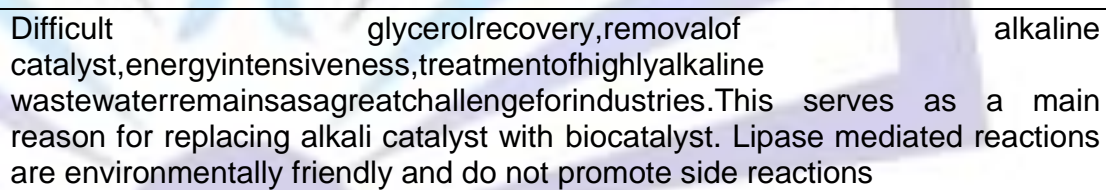 \\
\hline
\end{tabular}

To promote environmental sustainability, it is important to instill environmental awareness to students at a young age; and to also inform students about environment-friendly biodiesel sources, the importance of the sources in meeting the world's energy demands, and the respective areas of use for these biodiesel sources. Furthermore, teachers e who assumeimportant roles in raising awareness among students on various subjects e should themselves possess sufficient and adequate knowledge regarding biodiesel. The aim of the current study was to determine the level of awareness and concerns of twelve grade high school students in Jakarta regarding biodiesel, and to identify their opinions on the advantages and disadvantages of energy obtained by using biodiesel.

\section{Methodology}

The study was part of an research effort to explore school students' knowledge, perceptions, and attitudes related to biodiesel. The study was conducted with a total of 185 High school students from ten $(n=75)$ and twelve $(n=110)$ grades. Of these students, 86 were male and 99 were female. A pilot test was also conducted before the study among a group of twelve graders in another school in Jakarta to improve the final version of the questionnaire.

The original questionnaire used for the study had both open-ended and close ended items to measure students knowledge, perceptions, and attitudes related to biodiesel.A Likert-type scale (strongly agree to strongly disagree) was 
initially constructed with ten items to measure students' perceptions of biodiesel production from non edible oil and edible oil. However, the reliability analysis with Cronbach's Alpha suggested removing two items from the scale to improve the internal consistency of the scale. Finally, eight items were retained and the Cronbach's Alpha value became 0.77 , which showed adequate level of internal consistencyof the scale. A Cronbach's Alpha value equal to or greater than 0.70 has been considered acceptable in previous studies.

In the first stage about knowledge related biodiesel, three openended questions wereasked of the students to determine:

(1) "What would be the benefits of having a biodiesel, and (2) their current knowledge regarding biodiesel sources and

(3)" the type process production of biodiesel". In the second stage, a 7-item questionnaire was administered to the students. The study data were analyzed as percentages by using the SPSS statistical package program.

\section{Results}

\subsection{Students' knowledge of the benefits of having a biodiesel}

The percentage distributions of the student answers to the question, "What would be the benefits of having a biodiesel ?" are provided in Fig1.According to the students' answers, 82\% mentioned lower emission of carbon dioxide, as a type of biodiesel , while $78 \%$ described environmentally friendly , $58 . \%$ described non-toxic, $49 \%$ described, biodegradable, and $32 \%$ described economical, $22 \%$ decribed renewable, their family as their the benefits of biodiesel.

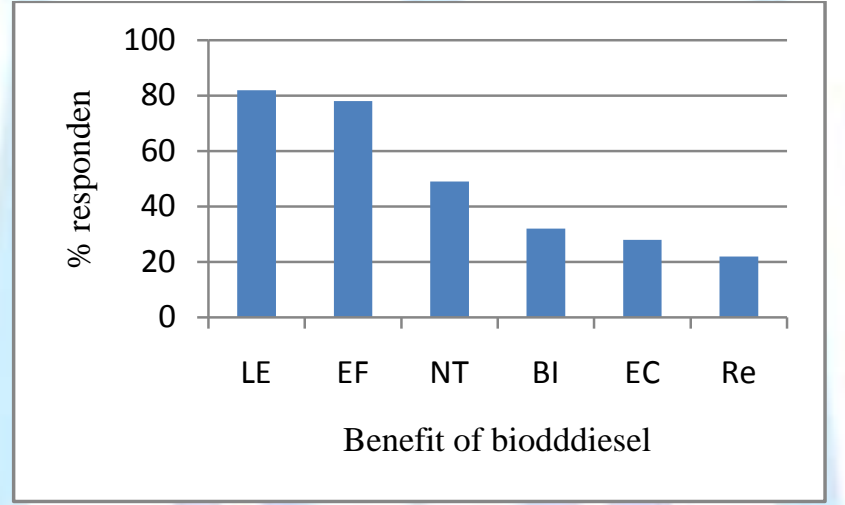

Fig 1. Benefits of having a biodiesel: $L E=$ lower emmision, $F=$ environmentally friendly, NT = non toxic, $\mathrm{BI}=$ biodgradable, $\mathrm{CE}=$ conomical, $\mathrm{Re}=$ renewable

\subsection{Students' knowledge of the sources of biodiesel}

The percentage distributions of the student answers to thequestion, "What are the sources of biodiesel?" are providedin Fig 2.According to the students' answers, $89 \%$ described the palm oil as a biodiesel source, while $75 . \%$ described waste cooking oil, $67 \%$ described microalga, $65 \%$ described the jatropha oil, $48 \%$ Canolla oil as biodiesel sources

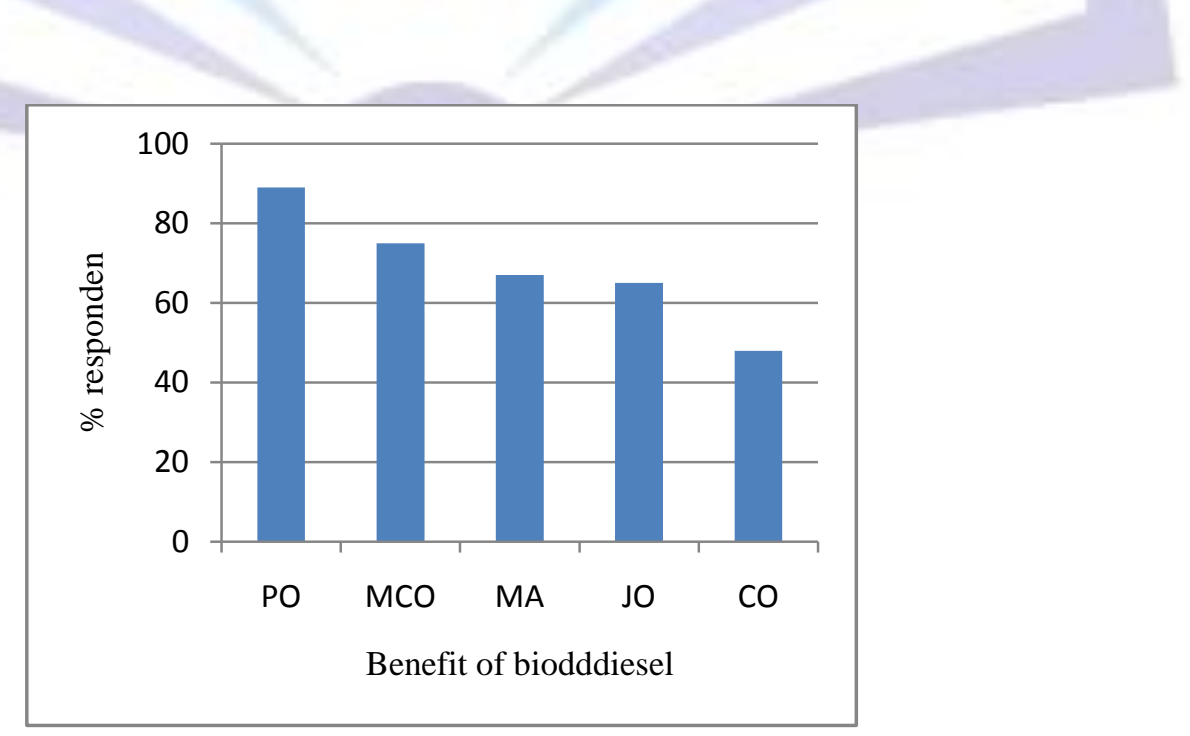

Fig 2. Student knowledge regarding sources of biodiesel: $\mathrm{PO}=$ palm oil, $\mathrm{WCO}=$ waste 
cooking oil, $\mathrm{MA}=$ micro alga, $\mathrm{JO}=$ Jatropha oil, $\mathrm{CO}=$ canolla oil,

\subsection{Students' knowledge ofthe types of biodiesel production processes}

The percentage distributions of the student answers to the question, "What are the types of biodiesel production processes? are provided in Fig 3. According to the students' answers, 91\% described transesterification with catalyst acid a type of synthesis of biodiesel, while $86 \%$ described transesterification with catalyst base, $28 \%$ describbed pyrolysis, as the other types of preparation of biodiesel.

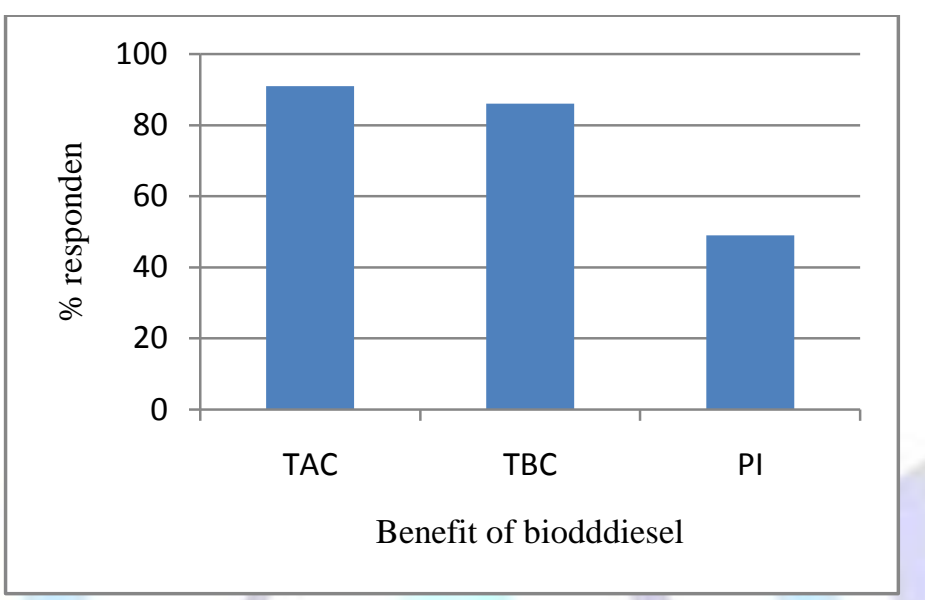

Fig 3. Student perceptions regarding the types of process production biodiesel.TAC = transesterfication with acid catalyst. $\mathrm{TBC}=$ transesterfication with base catalyst, $\mathrm{PI}=$

pyrolysis.

\subsection{Students' perceptions of biodiesel production from non edible oil and edible oil for heat and power}

Represents the results of the high school students' perceptions of biodieselproduction from non edible oil and edible oil are provided in Table 3.

Table 3

Represents the results of the high school students' perceptions of biodiesel production from non biodiesel oil and biodiesel oil

\begin{tabular}{|l|l|l|l|l|l|l|}
\hline No & Statement items & $\begin{array}{l}\text { Strongly } \\
\text { agree } \\
(\%)\end{array}$ & $\begin{array}{l}\text { Agree } \\
(\%)\end{array}$ & $\begin{array}{l}\text { Don't } \\
\text { Know } \\
(\%)\end{array}$ & $\begin{array}{l}\text { Disagree } \\
(\%)\end{array}$ & $\begin{array}{l}\text { Strongly } \\
\text { disagree } \\
(\%)\end{array}$ \\
\hline 1 & $\begin{array}{l}\text { Global warming would be reduced if more of our } \\
\text { electricity was made from renewable sources }\end{array}$ & 68 & 17 & 15 & & \\
\hline 2 & $\begin{array}{l}\text { Production of biodiesel from edible oil } \\
\text { environmentally friendly }\end{array}$ & 6 & 68 & 5 & 21 & - \\
\hline 3 & $\begin{array}{l}\text { Biodiesel combustion results in reduced emissions } \\
\text { CO } 2\end{array}$ & 6 & 80 & 4 & 10 & \\
\hline 4 & $\begin{array}{l}\text { Biodiesel would be a major source of bioenergy in } \\
\text { the future }\end{array}$ & 7 & 78 & 6 & 9 & \\
\hline 5 & $\begin{array}{l}\text { Biodiesel is renewable and sustainable } \\
\text { Transesterfication should be established for }\end{array}$ & 2 & 64 & 12 & 7 & \\
\hline 7 & $\begin{array}{l}\text { Different types of catalysts are employed in biodiesel } \\
\text { production }\end{array}$ & 29 & 45 & 3 & 5 & \\
\hline
\end{tabular}


Enzyme-catalyzed reactions are more environmentally friendly

Moreover, $17 \%$ of the students described that producing electricity mainly from renewable energy sources would reduce global warming. The students' answers to the questionnaire items also showed that $68 \%$ of them agreed with the observation that most teenagers look down on the idea of making electricity from renewable sources, and that these student tend to think those who support energy renewable sources are damaging the environment. Among the students, $15 \%$ expressed that they had no opinion on whether power stations that produce electricity from renewable sources cost more to shut down than the other types of power stations.

Regarding the Item 2, it appeared that about $21 \%$ of the students did not perceive production of biodiesel from edible oil as environmentally friendly while a much lesser number of them (about 21\%) perceived that type of biodiesel production on a positive note. About $86 \%$ of the students perceived biodiesel combustion results in reduced emissions $\mathrm{CO}_{2}$ as justified in comparison with $10 \%$ of the students who opposed to that notion.

The students' answers regarding the item 6-8 agreed aspects of process biodiesel production indicated that $64 \%$ considered it very agree to ensure that transterification with catalyst should be established for biodiesel production; $45 \%$ considered agree for biodiesel producing biodiesel catalyst is used to increases the reaction rate and enhances the solubility of alcohol and $49 \%$ considered it enzyme-catalyzed reactions are more environmentally friendly

The study results also demonstrated that most of the students believed that global warming was taking place, and that they were concerned regarding the serious consequences global warming might have; however, they still considered the amount of information they had on global warming as insufficient. In addition, the students were of the opinion that biodiesel use would reduce global warming, and that renewable energy sources are environment-friendly, non toxic and renewable.

The questionnaire items regarding global warming are provided in Table 4

Table 4

Questionnaire items.about global warning

\begin{tabular}{|l|l|}
\hline No & Question item \\
\hline 1 & $\begin{array}{l}\text { The increase in the global surface temperature is influenced by several factors including } \\
\text { anthropogenic and natural emissions of CO2, }\end{array}$ \\
\hline 2 & $\begin{array}{l}\text { The global warming will increase river water } \\
\text { temperature and evapotranspiration }\end{array}$ \\
\hline 3 & $\begin{array}{l}\text { Renewable energy, through the substitution of coal, oil, or } \\
\text { natural gas, will reduce CO2 emissions from energy system }\end{array}$ \\
\hline
\end{tabular}

The students' answers' regarding global warming indicated that $76 \%$ were very concerned about its effects on the environment.Furthermore, $24 \%$ of the students expressed that they knew alittle about global warming, Among the students, $90 \%$ considered that global warming can be reduce If we used the sun, wind and waves to make energy more .

\section{Conclusions}

Based on the study results, it was observed most of students believes that biodiesel have beeen benefit. In addition, the study also determined that biodiesel are lower emission of carbon dioxide, environmentally friendly, non-toxic, biodegradable, renewable, and economical

While the majority of the students correctly named the the palm oil, waste cooking oil, microalga and, jatropha oil, and asas sources of biodiesel. This illustrated that although most of the students knew about biodiesel sources. Furthermore, some of the students erroneously mentioned non biodiesel sources such as sewage, and sludge elements as biodiesel sources. This demonstrated that certain students could not correctly distinguish biodiesel and non biodiesel sources from one another.

The large majority of the students could mention transesterification with catalys as process to produce biodiesel, that only a small number of students mentioned pyrolysis as process to produce biodiesel. This observation illustrated that these students had erroneous information regarding the types of preparation of biodiesel.

The students' most critical perceptions of biodiesel production appeared to be regardingthe future prospect of biodiesel as a major source of bioenergy production. The apparent reasons for such critical perceptions among the highschool students are clear from this study yet itcould be attributed to their perceptions of the issues related to environmental aspects of biodiesel production from non edible oil and edible oil as well as establishment of plantations for producing biodiesel. 


\section{ACKNOWLEDGMENTS}

This work was included in a scientific Project State Univerciti of Jakarta about the valorisation of agroresources labelled Sustainable energy Project Number 203 from the Indonesia Ministry of Higher Education affairs.

\section{REFERENCES}

[1]. Intergovernmental Panel on Climate Change. In: Houghton JT, Ding Y,Griggs DJ, NoguerM, van der Linden PJ, Dai X, ., editors.2001. Climate change:the scientific basiccontribution of working group I to the third assessmentreport of the Intergovernmental Panel on Climate Change. Cambridge: CambridgeUniversity Press, IPCC.

[2]. Pimental D, Herz M, Glickstein M, Zimmerman M, Allen R, Becker K,.2002. Renewable energy: current and potential issues. Bioscience, 52:1111-1120.

[3] Daugherty MK, Carter VR.2010.Renewable energy technology. The TechnologyTeacher; p. 24-28

[4] Shahid EM, Jamal Y. 2008. A review of biodiesel as vehicular fuel. Renew Sustain Energy Rev ;12:2484-2894.

[5] Escobar JC, Lora ES, Venturini OJ, Yáñez EE, Castillo EF, Almazan O. 2009.Biofuel environment, technology and food security. Renew Sustain Energy Rev ;13:1275-1287

[6] Scrimgeour C. Chapter 1: chemistry of fatty acids.2005. In: Shahidi F, editor. Bailey's industrial oil and fat products: chemistry, properties, and health effects. Hoboken, New Jersey, USA: John Wiley \& Sons, Inc.;. pp. 1-44.

[7]Sharma YC, Singh B, Upadhyay SN. 2008.Advancements in development and characterization of biodiesel: a review. Fuel ;87:2355e73.

[8] Karmakar A., Karmakar S., Mukherjee S.2010. Properties of various plants and animals feedstocks for biodiesel production. Bioresource Technology

. [9] Ogunniyi. DS. 2006. Castoroil:avitalindustrialrawmaterial.2006.Bioresource Technology ;97:1086-91.

[10] HossainAK,DaviesPA.2010. Plantoilsasfuelsforcompressionignitionengines: a technicalreviewandlifecycleanalysis. RenewableEnergy;35:1-13

[11] AkbarE,YaakobZ,KamarudinSK,IsmailM,SalimonJ.2005.Characteristic and compositionof JatrophaCurcas oil seedfromMalaysiaandits potentialasbiodieselfeedstock. EuropeanJournalofScientificResearch ;29: 396-403

[12] Balat M, Balat H. Progress in biodiesel processing. Applied Energy 2010;87:1815-35.

[13] Demirbas A.2003. Biodiesel fuels from vegetable oils via catalytic and non- catalytic supercritical alcohol transesterifications and other methods: a survey. Energy ConversionandManagement ;44:2093-109.

[14] Agarwal AK.2007.Biofuels (alcohols and biodiesel) applications as fuels for internalcombustion engines. Progress in Energy and Combustion Science ;33:233-71.

[15] Clayton VM, Larry CM, Yan B, Daniel TN, Mark R, Arlin EG, Brian JK, Ronald LF, Thomas RH.2008.A continuous catalytic system for biodiesel production. AppliedCatalysis A: General;343:39-48.

[16] Dennis YC, Leung Xuan W, Leung MKH. 2010.A review on biodiesel production using catalyzed transesterification. Applied Energy ;87:1083-95.

[17] Karmakar A., Karmakar S., Mukherjee S. Properties of various plants and animals feedstocks for biodiesel production. Bioresource Technology 2010 